\title{
NUMBER OF PASSES IN MECHANICAL THROMBECTOMY: WHERE IS YOUR LIMIT?
}

\author{
A. FILIOGLO, J.E. COHEN, N. SIMAAN, \\ A. HONIG, R.R. LEKER
}

Hadassah-Hebrew University Medical Center, Jerusalem, Israel

\begin{abstract}
*Conflict of Interest Statement (We declare that we have no conflict of interest).
*Заява про конфлікт інтересів (Ми заявляємо, що у нас немає ніякого конфлікту інтересів).

*Заявление о конфликте интересов (Мы заявляем, что у нас нет никакого конфликта интересов).

*No human/animal subjects policy requirements or funding disclosures.

*Жодний із об'єктів дослідження (людина/тварина) не підпадає під вимоги політики щодо розкриття інформації фінансування.

*Ни один из объектов исследования не подпадает под политику раскрытия информации финансирования.
\end{abstract}

*Date of submission - 03.09.20

*Дата подачі рукопису - 03.09.20

*Дата подачи рукописи - 03.09.20
*Date of acceptance - 09.09.20

*Дата ухвалення - 09.09.20

*Дата одобрения к печати - 09.09.20

Background and aims. Stent retriever based thrombectomy is the mainstay of treatment of acute ischemic stroke caused by large vessel occlusion. However, recanalization is sometimes not achieved even after multiple passes of the thrombectomy device. Whether revascularization becomes futile or harmful with an increasing number of passes as well as criteria for when to halt attempting recanalization remain unknown. The purpose of our work is to analyze literature data on this issue.

Materials and methods. We performed a short review of the literature and summarized evidence on the impact of repeated stentriever attempts on outcome.

Results. Despite some controversies, the published data indicate that up to $30 \%$ of patients still reach favorable outcome even when $\geq 5$ stentriever passes are performed. Probability of obtaining functional independence after multiple stentriever attempts is even higher in patients with lower baseline NIHSS score. Patients who achieve successful reperfusion after $\geq 5$ passes have significantly higher rates of functional independence and significantly lower rates of hemorrhagic transformation compared with those who do not achieve reperfusion. Rate of target recanalization after $\geq 4$ passes may reach $19 \%$. Number of passes alone is not an independent negative predictor of functional independence. The impact of multiple stentriever attempts on hemorrhagic transformation has not been well-established.

Conclusions. Target vessel recanalization is an essential goal of mechanical thrombectomy, which should be pursued despite the additional number of passes and procedural time required. Number of stentriver attempts is not a game-changing factor in the deci- 
sion to abort the procedure for technical futility. Treatment decisions need to be individualized for each patient based on operator's experience and preferences, patient and clotspecific characteristics.

Key words: stroke; thrombectomy; stentriever; outcome.

Endovascular thrombectomy is the standard of care in acute ischemic stroke caused by large vessel occlusion [1]. Previous studies have provided convincing evidence that first-pass complete reperfusion strongly correlates with higher rates of favorable outcomes, lower mortality, and fewer procedural adverse events [2-5]. These findings may be explained by the fact that single pass thrombectomy produces less endothelial vascular trauma, increases chances of complete recanalization by reducing clot-vessel interactions and risks of distal embolization and requires faster procedural time. However, target recanalization after first thrombectomy pass is possible in only $22-57 \%$ of the patients depending on the primary endovascular technique, location and characteristics of the clot, vascular anatomy, etc. Hence, there is no clear consensus regarding algorithm of treatment of the patients in whom recanalization failed even after multiple clot retrieval attempts, and decision to abort the procedure mostly depends on the individual operator's experience and not based on empirical evidence.

Which should be the minimum degree of recanalization achieved before stopping the procedure? Where is a specific breaking point for switching to the rescue endovascular modality? When detrimental effects of multiple stentriever passes outweigh the benefit of recanalization? Many researches tried to give an answer to these questions and to investigate correlation between number of passes and outcomes.

García-Tornel et al. [6] performed an analysis on the impact of the total number of

Andrei FILIOGLO

$M D$, neurology

Stroke fellow, Department of Neurology,

Hadassah-Hebrew University Medical Center

Address: Kiryat Hadassah, P.O. Box 12000, 91120,

Jerusalem, Israel,

Phone: +972504048566

E-mail: afilioglo@gmail.com

ORCID ID: 0000-0002-4200-3141 passes according to reperfusion grade. They found that both, first pass recanalization and final mTICI 3 were independent predictors of good outcome. They also concluded, that the detrimental effect of each additional pass is counterbalanced by the benefits of a complete recanalization for up to 3 passes. Beyond that number of attempts, outcome is affected despite full recanalization. In contrast, for patients not achieving a TICI 3 recanalization the impact of additional passes negatively influence outcome starting from the second attempt. However, more than $40 \%$ of the patients in their cohort still had a good functional outcome even if recanalization was achieved after a third pass. Moreover, recanalization improved outcomes until up to 4 passes. Patients who achieved recanalization after $\geq 5$ passes had numerically better outcome but didn't achieve statistical significance. Thus, the authors proposed that additional attempts to achieve recanalization should be pursued at least until 4 passes.

Baek et al. [7] tried to find a specific break point at which the outcomes of patients with successful recanalization are not significantly more favorable than those of patients without recanalization. They found that if recanalization was achieved by $\geq 5$ stentriever passes, patient outcomes were not significantly more favorable than among patients without recanalization. Moreover, they concluded that recanalization after $\geq 4$ passes is an infrequent phenomenon occurring in $<10 \%$ of patients. Therefore, they recommended that successful recanalization should be achieved within 4 stentriever passes or a time from puncture to recanalization of 125 minutes in patients with baseline ASPECTS $>7$ and within 3 stentriever passes and time from puncture to recanalization of 60 minutes in subgroup of the patients with ASPECTS $\leq 7$. Otherwise, they suggested to consider switching to rescue endovascular modalities. These recommendations are in line with previously published report [8], which stated, that the probability 
of successful recanalization decreases below $50 \%$ if recanalization is not achieved within 5 thrombectomy maneuvers and that there is almost no chances of a good clinical outcome after 4 thrombectomy maneuvers.

However, a recently published study conducted by our group [9] showed different results. Our results indicate that $30 \%$ of patients still reach favorable outcome even when $\geq 5$ stentriever passes are performed. Probability of obtaining functional independence after $\geq 5$ attempts was even higher in patients with lower initial stroke severity. Recanalization rate in our series was $19 \%$ after $\geq 4$ passes and $12 \%$ after $\geq 5$ passes, which is significantly higher, than in previous reports. Our findings also indicated, that non-recanalizers had significantly higher rates of hemorrhagic transformation and significantly lower rates of functional independence compared with the patients that needed $\geq 5$ passes but did achieve favorable recanalization.

Similar results were reported by Tonetti et al. [10], who showed, that patients who achieve successful reperfusion after $\geq 4$ passes have significantly better rates of functional outcomes than those who do not achieve reperfusion. Furthermore, no patient with TICI $2 \mathrm{a}$ or worse reperfusion achieved favorable outcome. Number of passes required for recanalization was not a predictor of functional independence in their series. These findings are further supported by the findings of Jindal et al. [11], who also found that the number of thrombectomy attempts alone was not an independent negative predictor of functional

\section{References}

1. Goyal M, Menon BK, van Zwam WH et al. Endovascular thrombectomy after large-vessel ischaemic stroke: a meta-analysis of individual patient data from five randomised trials. Lancet. 2016;387(10029):1723-31. PMID: 26898852 DOI: 10.1016/S0140-6736(16)00163-X.

2. Kharouba R, Gavriliuc P, Yaghmour NE et al. Number of stentriever passes and outcome after thrombectomy in stroke. J Neuroradiol. 2019;46(5):32730. PMID: 30981826 DOI: $10.1016 /$ j.neurad.2019.03.014.

3. Zaidat OO, Castonguay AC, Linfante I et al. First pass effect: a new measure for stroke thrombectomy de- outcome, and concluded that revascularization beyond the first pass should continue to be the goal of stroke thrombectomy.

The impact of procedural factors such as stent retriever passes on hemorrhagic transformation of the stroke has not been wellestablished. While some studies [12] stated that there is an increased risk of parenchymal hematoma after $\geq 3$ stentriever passes, others failed to reproduce these results [13].

Therefore, we suggest that target vessel recanalization is an essential goal of mechanical thrombectomy, which should be pursued despite the additional number of passes and procedural time required. Although number of SR passes is a treatment effect modifier and a surrogate marker of procedural time and complexity, it is not an independent predictor of functional independence. Moreover, it shouldn't become a crucial factor in the decision to abort the procedure for technical futility. Nevertheless, our arguments should not be interpreted as suggestive for continuous endless efforts to achieve favorable recanalization with the same method. Conversely, combination with contact clot aspiration, balloon angioplasty or implantation of a stent may be far more efficacious in some patients than repeated stentriever attempts. Rather, we consider that treatment decisions need to be individualized for each patient, and decision of switching to a rescue modality should be left to the operator experience and preferences. Further research should focus on developing means of determining the optimal endovascular strategy for each patient.

vices. Stroke. 2018;49(3):660-6. PMID: 29459390 DOI: 10.1161/STROKEAHA.117.020315.

4. Nikoubashman O, Dekeyzer S, Riabikin A et al. True first-pass effect. Stroke. 2019;50(8):2140-6. PMID: 31216965 DOI: 10.1161/STROKEAHA. 119.025148 .

5. Angermaier A, Michel P, Khaw AV et al. Intravenous thrombolysis and passes of thrombectomy as predictors for endovascular revascularization in ischemic stroke. J Stroke Cerebrovasc Dis. 2016;25(10):2488-95. PMID: 27495833 DOI: 10.1016/j.jstrokecerebrovasdis.2016.06.024.

6. Garcia-Tornel A, Requena M, Rubiera M et al. When to stop. Stroke. 2019; 50(7):1781-8. PMID: 31177974 DOI: $10.1161 /$ STROKEAHA.119.025088. 
7. Baek JH, Kim BM, Heo JH et al. Number of stent retriever passes associated with futile recanalization in acute stroke. Stroke. 2018;49(9):2088-95. PMID: 30354993 DOI: 10.1161/STROKEAHA. 118.021320 .

8. Seker F, Pfaff J, Wolf M et al. Correlation of thrombectomy maneuver count with recanalization success and clinical outcome in patients with ischemic stroke. AJNR Am J Neuroradiol. 2017;38(7):136871. PMID: 28473346 DOI: 10.3174/ajnr.A5212.

9. Filioglo A, Cohen JE, Honig A, et al. More than five stentriever passes: real benefit or futile recanalization. Neuroradiology. 2020; Oct;62(10):13351340. PMID: 32556423 DOI: 10.1007/s00234020-02469-x.

10. Tonetti DA, Desai SM, Casillo S et al. Successful reperfusion, rather than number of passes, predicts clinical outcome after mechanical thrombectomy. J Neurointerv Surg. 2020;12(6):548-51. PMID: 31676689 DOI: $10.1136 /$ neurintsurg-2019-015330.
11. Jindal G, Carvalho HP, Wessell A et al. Beyond the first pass: revascularization remains critical in stroke thrombectomy. J Neurointerv Surg. 2019;11(11):1095-9. PMID: 31048458 DOI: 10.1136/neurintsurg-2019-014773.

12. Bourcier R, Saleme S, Labreuche J, MazighiM, Fahed R, Blanc R, Gory B, Kyheng M, Marnat G, Bracard S, Desal H, Consoli A, Piotin M, Lapergue B, ASTER Trial Investigators. More than three passes of stent retriever is an independent predictor of parenchymal hematoma in acute ischemic stroke. J Neurointerv Surg. 2019;11(7):6259. PMID: 30389897 DOI: $10.1136 /$ neurintsurg-2018-014380.

13. Hassan AE, Kotta H, Shariff $U$ et al. There is no association between the number of stent retriever passes and the incidence of hemorrhagic transformation for patients undergoing mechanical thrombectomy. Front Neurol. 2019; 10:818. PMID: 31440198 DOI: $10.3389 /$ fneur.2019.00818.

\title{
КІЛЬКІСТЬ ПІДХОДІВ ПРИ МЕХАНІЧНІЙ ТРОМБЕКТОМЇ̈: КОЛИ ЗУПИНИТИСЯ?
}

\author{
A. Filioglo, J.E. COHEN, N. SIMAAN, A. HONIG, R.R. LEKER \\ Медичний Центр Хадасса - Сврейський університет, м. Єрусалим, Ізраїль
}

Передумови та цілі. Тромбектомія з використанням стент-ретриверів $\epsilon$ основою лікування гострого ішемічного інсульту внаслідок оклюзії великих судин. Однак іноді реканалізації не досягають навіть після багаторазових підходів. Невідомо, чи стає реваскуляризація неефективною чи навіть шкідливою зі збільшенням кількості підходів, а також коли слід залишити спроби реканалізації. Мета роботи - проаналізувати дані літератури щодо цього питання.

Матеріали та методи. Наведено короткий огляд літератури. Узагальнено докази впливу багаторазових спроб тромбекстракції стент-ретривером на результат лікування.

Результати. Незважаючи на деяку суперечливість, опубліковані дані вказують на те, що майже у 30 \% пацієнтів досягають сприятливого результату, навіть після $\geq 5$ проходів стент-ретривером. Імовірність функціональної незалежності після багаторазових спроб реканалізації стент-ретривером вища у пацієнтів з нижчим базовим показником за NIHSS. Пацієнти, в яких досягнуто успішної реперфузії після $\geq 5$ проходів, мають значно вищі показники функціональної незалежності та значно нижчі показники геморагічної трансформації порівняно з особами, в яких реперфузії не досягнуто. Рівень реканалізації після $\geq 4$ проходів може становити 19 \%. Кількість проходів сама по собі не є незалежним негативним предиктором функціональної незалежності. Також не встановлено впливу багаторазових проходів стент-ретривером на геморагічну трансформацію.

Висновки. Реканалізація судини-мішені є основною метою механічної тромбектомії, незважаючи на додаткову кількість підходів та процедурний час. Кількість проходів стент-ретривером не є чинником, який впливає на прийняття рішення про відмову від процедури через технічну неефективність. Рішення щодо лікування слід приймати індивідуально з урахуванням досвіду та уподобань оператора, особливостей пацієнта і тромбу.

Ключові слова: інсульт; тромбектомія; стент-ретривер; результати лікування. 


\title{
КОЛИЧЕСТВО ПОДХОДОВ ПРИ МЕХАНИЧЕСКОЙ ТРОМБЭКТОМИИ: КОГ- ДА ОСТАНОВИТЬСЯ?
}

\author{
A. Filioglo, J.E. COHEN, N. SIMAAN, A. HONIG, R.R. LEKER
}

Медицинский Центр Хадасса - Еврейский университет, г. Ерусалим, Израиль

Предпосылки и цели. Тромбэктомия с использованием стент-ретриверов является основой лечения острого ишемического инсульта вследствие окклюзии крупных сосудов. Однако иногда реканализации не достигают даже после многократных подходов. Не известно, становится ли реваскуляризация неэффективной или даже вредной с увеличением количества подходов, а также когда следует оставить ее попытки. Цель работы проанализировать данные литературы по этому вопросу.

Материалы и методы. Приведен краткий обзор литературы. Обобщены доказательства влияния многократных попыток тромбэкстракции стент-ретривером на результат лечения.

Результаты. Несмотря на некоторую противоречивость, опубликованные данные указывают на то, что почти у 30 \% пациентов достигают благоприятного результата даже после $\geq 5$ проходов стент-ретривером. Вероятность функциональной независимости после многократных попыток реканализации стент-ретривером выше у пациентов с низким базовым показателем по NIHSS. Пациенты, у которых достигнута успешная реперфузия после $\geq 5$ проходов, имеют значительно более высокие показатели функциональной независимости и значительно более низкие показатели геморрагической трансформации по сравнению с лицами, у которых реперфузия не была достигнута. Уровень реканализации после $\geq 4$ проходов может составлять 19 \%. Количество проходов само по себе не является независимым негативным предиктором функциональной независимости. Также не установлено влияния многократных проходов стентретривером на геморрагическую трансформацию.

Выводы. Реканализация сосуда-мишени является основной целью механической тромбэктомии, несмотря на дополнительное количество подходов и время процедуры. Количество проходов стент-ретривером не является фактором, влияющим на принятие решения об отказе от процедуры из-за технической неэффективности. Решение относительно лечения следует принимать индивидуально с учетом опыта и предпочтений оператора, особенностей пациента и тромба.

Ключевые слова: инсульт; тромбэктомия; стент-ретривер; результаты лечения. 